\title{
Comparison of body mass reduction obtained with RYGB and SG bariatric procedures and with a reduction diet - procedures versus reduction diet
}

\section{Porównanie redukcji masy ciała u pacjentów po operacji bariatrycznej metodą RYGB i SG oraz przy zastosowaniu diety redukcyjnej - operacje kontra dieta redukcyjna}

\author{
Małgorzata Szczuko ${ }^{凶}$, Natalia Komorniak, Agata Jaroszek
}

Pomorski Uniwersytet Medyczny w Szczecinie, Zakład Biochemii i Żywienia Człowieka, ul. Broniewskiego 24, 71-460 Szczecin Pomeranian Medical University in Szczecin, Department of Biochemistry and Human Nutrition

$\triangle$ malgorzata.szczuko@pum.edu.pl

\begin{abstract}
Introduction: Extreme obesity is becoming a more common health problem, and the growing popularity of bariatric procedures seems to be a good solution in the pursuit of reaching a proper body weight and to improve health.

The aim of this study was to determine whether bariatric procedures are more effective than a rational reduction diet in obtaining body weight reduction and an appropriate intake of nutrients. Materials and methods: The analyses were performed among 40 female patients admitted for bariatric surgery using gastric bypass or sleeve gastrectomy. The average age of women was 42.96 (SD 10.45) years, average body weight was $131.56 \mathrm{~kg}$ (SD 14.18) with average height of $168.37 \mathrm{~cm}$ (SD 8.69). All statistical analyses were performed using Statistica 12.

Results: The loss of body weight on the reduction diet after 13 months ranged from $26-42 \mathrm{~kg}$, depending on the level of physical activity. In the group of patients after bariatric surgery the
\end{abstract}

average body weight reduction after 13 months was $31.87 \mathrm{~kg}$. The reduction diet and the diet after surgery were prepared according to the Diet 5 software recommended by Institute of Food and Nutrition (Instytut Żywności i Żywienia) in Poland. The diet after the bariatric procedure contained $1237 \mathrm{kcal}$ and comprised $26.9 \%$ protein, $34.6 \%$ fat and $38.5 \%$ carbohydrates. The diet for patients after the surgery provided insufficient levels of potassium, calcium, magnesium, iron, zinc, iodine, vitamins: E, B1, D, folic acid and dietary fibre.

Conclusions: Body mass reduction achieved by proper diet and increased physical activity can be equally effective in obesity treatment as bariatric procedures. It also poses lesser risk of complications and potential deficiencies in nutrients. It seems that in both cases the long-term support of a dietician and a psychologist is necessary in order to develop healthy eating habits. Keywords: body mass reduction; bariatric surgery; reduction diet; Roux-en-Y gastric bypass; sleeve gastrectomy.

\begin{abstract}
ABSTRAKT
Wstęp: Otyłość olbrzymia staje się coraz większym problemem zdrowotnym, a rosnąca popularność operacji bariatrycznych wydaje się dobrym rozwiązaniem w walce o uzyskanie prawidłowej masy ciała i poprawę zdrowia.

Celem pracy było zbadanie, czy operacje bariatryczne są skuteczniejsze od zastosowania racjonalnej diety redukcyjnej w uzyskaniu redukcji masy ciała i prawidłowej podaży składników pokarmowych.

Materiały i metody: Badania zostały przeprowadzone wśród 40 pacjentek zgłaszających się na operacje bariatryczne metodą ominięcia żołądkowo-jelitowego lub rękawowej resekcji żołądka. Średnia wieku kobiet wynosiła 43,7 (SD 24,4) lat, średnia masa ciała 127,7 kg (SD 11,3), przy średnim wzroście 168,14 cm (SD 7,5). Obliczenia statystyczne wykonano przy użyciu programu Statistica 12.

Wyniki: Utrata masy ciała na diecie redukcyjnej przez okres 13 miesięcy wynosi 26-42 kg w zależności od aktywności fizycznej. W grupie pacjentów po operacji bariatrycznej średni ubytek
\end{abstract}

masy ciała po 13 miesiącach wyniósł ok. 33 kg (SD 14,33). Dieta redukcyjna po operacji była układana zgodnie z zaleceniami przy użyciu programu Dieta 5 rekomendowanego przez Instytut Żywności i Żywienia. Dieta po operacji bariatrycznej charakteryzowała się kalorycznością $1237 \mathrm{kcal}$, w tym odsetek z białka $26,9 \%$, tłuszczu 34,6\%, węglowodanów 38,4\%. Dieta pacjentek po operacji była niedoborowa pod względem podaży potasu, wapnia, magnezu, żelaza, cynku, jodu, witamin E, B1, D, kwasu foliowego i błonnika pokarmowego.

Wnioski: Redukcja masy ciała odpowiednią dietą oraz poprzez zwiększenie aktywności fizycznej może być skuteczniejszą metodą w leczeniu otyłości niż operacje bariatryczne. Stwarza mniejsze ryzyko komplikacji oraz wystąpienia niedoborów żywieniowych. W obu przypadkach niezbędna jest długoterminowa pomoc dietetyka i psychologa oraz wypracowanie prawidłowych nawyków ży wieniowych.

Słowa kluczowe: redukcja masy ciała; dieta redukcyjna; operacja bariatryczna; ominięcie żołądkowo-jelitowe; rękawowa resekcja żołądka. 


\section{INTRODUCTION}

Obesity is a chronic disease which can be determined genetically [1], but its occurrence within the family can also be caused by environmental factors, such as the lack of physical activity, high calorie diet and consumption of cheap food of low quality [2]. Obesity facilitates the development of many diet-related diseases linked to the presence of metabolic syndrome, a state when adipose tissue comprises of more than $25 \%$ of total body weight in men and 30\% in women [3]. The basic way to fight obesity is to introduce a rational diet, develop proper dietary habits and increase physical activity. Reducing the daily caloric intake by $500 \mathrm{kcal}$ below the daily requirements enables to reduce the body mass by ca. $0.5 \mathrm{~kg}$ a week, and with increased physical activity one can achieve even better results [4]. Caloric intake, however, should never drop below basal metabolic rate (BMR) because it triggers the mechanisms buffering body weight loss $[5,6]$.

Reducing weight by reducing caloric intake is a long-time process and can be ineffective in case of people with hormonal or metabolic disorders, with genetic load or low physical activity. Bariatric surgery seems to be the quickest and thus the most effective way to reduce body weight and treat pathological obesity [7]. However, it also poses many health risks often unknown to patients before the surgery. The medical indications for surgical obesity treatment are, among others, high body mass index (BMI) - above $40 \mathrm{~kg} / \mathrm{m}^{2}$, high blood pressure, type 2 diabetes, metabolic syndrome, osteoarthritis, restrictive ventilatory defects and numerous ineffective dietary interventions. For the process of body weight reduction to be effective in long-term the patient should be supported by a qualified dietician, whose responsibility would be to prepare the patient to the procedure, help in develop proper dietary habits, increase the patient's physical activity and guide through the early post-operative period [8]. Maintaining new dietary habits and changed lifestyle are crucial in keeping the results of bariatric surgery. Psychological support is also important, because such patients are susceptible to depression related to the lack of self-acceptance [9].

The two aforementioned bariatric procedures are significantly different [10]. In the method called RouX-en-Y bypass (RYGB) the stomach is divided below the lower stomach outlet horizontally into two parts. The upper part forms smaller stomach pouch connected to small intestine loop via a "Roux limb". Lower part remains physiologically linked to duodenum and proximal part of jejunum, through which the bile and digestive enzymes are transported. Digestion and absorption are thus limited, because they occur on a shorter distance of the gastrointestinal tract. This method is especially recommended for the patients called "sweet eaters". The length of the bypass and the size of the upper stomach are adjusted individually for each patient. The advantage of this method is higher average reduction of body mass [11]. The disadvantages of this method include frequent post-operative complications and the necessity of lifelong supplementation in vitamins and minerals and regular control of their level in the organism due to potential deficiencies.

Sleeve gastrectomy (SG) is based on the surgical removal of ca. $70-80 \%$ of the stomach along the greater curvature. The remaining part forms a narrow sleeve with intact outlet near the pylorus. This method is especially recommended for binge eaters. The mechanism of the procedure consists in the reduction of the volume of consumed food and hunger due to decreased secretion of ghrelin and reduced appetite nerve signalling in hypothalamus $[12,13]$. Sleeve gastrectomy is often selected for patients with menstrual obesity $\left(\mathrm{BMI}>50 \mathrm{~kg} / \mathrm{m}^{2}\right)$, for whom it is the first part of the two-stage surgical obesity treatment. The period between the surgery and the stabilization of the body weight is considered as starvation period with all its consequences and it lasts for ca. 2 years.

Therefore, the least invasive method of body mass and adipose tissue reduction is a properly balanced diet. The advantages of its use are greater in many aspects. However, the popularity of bariatric surgeries grows, despite the fact that patients do not have appropriate dietary care.

The aim of this study was to determine which methods: bariatric surgery RYGB and SG type or rational reduction diet is more effective in achieving weight reduction. Our task was also to consider the correct supply of nutrients and the health consequences resulting from both methods.

\section{MATERIALS AND METHODS}

\section{Test group}

To perform the study reported their scope on the Bioethics Committee of the Pomeranian Medical University in Szczecin (No. KB-0012/34/04/2014). Examined groups of bariatric patients (RYGB and SG) did not differ significantly with respect to anthropometric and biochemical parameters. The average age of 40 women in the test group was $42.96 \pm 10.45$. The average body weight was $131.5 \pm 14.18 \mathrm{~kg}$ and waist circumference $139.2 \pm 14.33 \mathrm{~cm}$. Besides obesity, in $56.25 \%$ of women diet-related diseases were present, and other women were qualified for surgery due to numerous attempts to treat obesity using diets with no successful effects. Women were treated using one of the bariatric procedures - SG or RYGB. The decision on which method would be selected was based on the criteria presented in the table below and personal questionnaire (Table 1). Anthropometric measurements were performed with

TABLE 1. Criteria for selection of the method of bariatric treatment

\begin{tabular}{lll}
\multicolumn{1}{c}{ Criterion } & Roux-en-Y bypass & \multicolumn{1}{c}{ Sleeve gastrectomy } \\
\hline Age & $\begin{array}{l}\text { younger people } \\
<30 \text { years of age }\end{array}$ & $>30$ years of age \\
\hline $\begin{array}{l}\text { Body mass } \\
\text { index }\end{array}$ & $<50$ & $>50$ \\
\hline $\begin{array}{l}\text { Accompanying } \\
\text { diseases }\end{array}$ & $\begin{array}{l}\text { metabolic } \\
\text { (mainly diabetes) }\end{array}$ & $\begin{array}{l}\text { without diseases ("anti-incretin" } \\
\text { theory of diabetes remission) }\end{array}$ \\
\hline Dietary habits & "sweet eaters" & $\begin{array}{l}\text { people who gorge themselves, } \\
\text { large volume meals }\end{array}$
\end{tabular}


TABLE 2. Characteristics of the test group of women before the surgery

\begin{tabular}{lccc}
\multicolumn{1}{c}{ Parameter } & $\begin{array}{c}\text { Total } \\
\text { (SG }+ \text { RYGB) }\end{array}$ & RYGB & SG \\
\hline Age* (years) & $42.96 \pm 10.45$ & $42.97 \pm 10.10$ & $42.95 \pm 10.53$ \\
\hline Body weight* $(\mathrm{kg})^{1}$ & $131.56 \pm 14.18$ & $130.08 \pm 14.41$ & $132.32 \pm 13.88$ \\
\hline Height* $(\mathrm{cm})^{168.37 \pm 8.69}$ & $168.49 \pm 8.71$ & $168.12 \pm 8.75$ \\
\hline $\begin{array}{l}\text { Waist circum- } \\
\text { ference* }(\mathrm{cm})\end{array}$ & $139.2 \pm 14.33$ & $138.38 \pm 13.97$ & $140.15 \pm 14.98$ \\
\hline $\begin{array}{l}\text { Hip circumference* } \\
\text { (cm) }\end{array}$ & $143.50 \pm 13.73$ & $142.77 \pm 14.01$ & $144.23 \pm 12.87$ \\
\hline $\begin{array}{l}\text { Body mass index* } \\
\left(\mathrm{kg} / \mathrm{m}^{2}\right)\end{array}$ & $46.49 \pm 6.78$ & $45.82 \pm 6.66$ & $46.81 \pm 7.06$ \\
\hline \begin{tabular}{l} 
WHR* \\
\hline
\end{tabular} & $1.02 \pm 0.11$ & $1.02 \pm 0.10$ & $1.02 \pm 0.11$ \\
\hline
\end{tabular}

SG - sleeve gastrectomy; RYGB - Roux-en-Y bypass; WHR - waist to hip ratio * no statistically significant differences ( $p>0.05)$

$0.5 \mathrm{~cm}$ and $0.1 \mathrm{~kg}$ accuracy (body weight, height, waist circumference, hip circumference). No significant differences were observed between the tested groups (Table 2).

\section{Dietary recommendations for patients reducing weight through the change of lifestyle}

A 7-day reduction diet was developed based on the recommendations of Ciborowska and Rudnicka: Dietetics, nutrition of healthy and sick person [14]. The diet assumed physical activity index of 1.4. Daily caloric intake after a 500-800 kcal reduction was, on average, $1930 \mathrm{kcal}$, including $18 \%$ energy from

TABLE 3. Energy and nutrients contents in compared diets

\begin{tabular}{|c|c|c|c|c|}
\hline \multirow[t]{2}{*}{ Component } & \multicolumn{2}{|c|}{$\begin{array}{l}\text { Initial diet after } \\
\text { bariatric surgery }\end{array}$} & \multicolumn{2}{|c|}{$\begin{array}{c}\text { Reduction diet } \\
\text { for patients } \\
\text { not subjected } \\
\text { to bariatric surgery }\end{array}$} \\
\hline & average & SD & average & SD \\
\hline Energy (kcal) & $1236.99^{*}$ & 111.56 & 1930.16 & 107.53 \\
\hline Water (g) & $668.95^{*}$ & 76.39 & 1321.30 & 151.28 \\
\hline Total protein (g) & $72.88^{*}$ & 9.58 & 93.52 & 12.41 \\
\hline Animal protein (g) & 53.25 & 10.31 & 51.58 & 15.17 \\
\hline Plant protein (g) & $11.63^{*}$ & 3.21 & 42.30 & 9.36 \\
\hline Fat (g) & $50.60^{\star}$ & 6.16 & 62.64 & 9.43 \\
\hline $\begin{array}{l}\text { Total } \\
\text { carbohydrates (g) }\end{array}$ & $128.03^{*}$ & 17.30 & 281.38 & 22.09 \\
\hline Ash (g) & $9.48^{*}$ & 1.18 & 17.26 & 0.65 \\
\hline Sodium (mg) & 1432.69 & 524.35 & 1691.99 & 491.74 \\
\hline Potassium (mg) & $2055.55^{*}$ & 335.98 & 4421.33 & 649.54 \\
\hline Calcium (mg) & $525.44^{*}$ & 186.81 & 932.31 & 279.11 \\
\hline Phosphorus (mg) & $1154.85^{*}$ & 138.48 & 1910.24 & 194.73 \\
\hline Magnesium (mg) & $234.78^{*}$ & 50.53 & 533.72 & 26.36 \\
\hline Iron (mg) & $7.05^{*}$ & 1.39 & 14.55 & 1.89 \\
\hline Zinc (mg) & $7.44^{*}$ & 1.63 & 13.70 & 1.08 \\
\hline Copper (mg) & $0.79^{\star}$ & 0.13 & 1.84 & 0.25 \\
\hline Manganese (mg) & $3.59^{*}$ & 0.78 & 8.08 & 1.52 \\
\hline Vitamin A $(\mu g)$ & $803.89^{\star}$ & 400.28 & 1766.58 & 760.49 \\
\hline Retinol $(\mu g)$ & 220.63 & 66.66 & 220.02 & 64.56 \\
\hline Beta-carotene $(\mu g)$ & $3635.67^{*}$ & 2605.42 & 9280.41 & 4331.15 \\
\hline
\end{tabular}

\begin{tabular}{|c|c|c|c|c|}
\hline \multirow[t]{2}{*}{ Component } & \multicolumn{2}{|c|}{$\begin{array}{l}\text { Initial diet after } \\
\text { bariatric surgery }\end{array}$} & \multicolumn{2}{|c|}{$\begin{array}{l}\text { Reduction diet } \\
\text { for patients } \\
\text { not subjected } \\
\text { to bariatric surgery }\end{array}$} \\
\hline & average & SD & average & SD \\
\hline Vitamin E (mg) & $7.40^{*}$ & 1.50 & 17.05 & 3.28 \\
\hline Thiamine (mg) & $0.81^{*}$ & 0.42 & 1.81 & 0.22 \\
\hline Riboflavin (mg) & $1.49^{*}$ & 0.24 & 2.15 & 0.24 \\
\hline Niacin (mg) & $14.24^{*}$ & 5.35 & 24.04 & 1.83 \\
\hline Vitamin B6 (mg) & $1.65^{*}$ & 0.29 & 2.89 & 0.58 \\
\hline Vitamin C (mg) & $97.55^{*}$ & 55.52 & 320.84 & 102.24 \\
\hline $\begin{array}{l}\text { Total fatty acids - } \\
\text { saturated (g) }\end{array}$ & 15.35 & 4.31 & 18.07 & 4.63 \\
\hline $\begin{array}{l}\text { Total fatty acids - } \\
\text { monounsaturated (g) }\end{array}$ & $15.88^{*}$ & 3.17 & 26.28 & 4.30 \\
\hline $\begin{array}{l}\text { Total fatty acids - } \\
\text { polyunsaturated (g) }\end{array}$ & $6.11^{*}$ & 2.01 & 13.41 & 2.96 \\
\hline Cholesterol (mg) & 178.80 & 101.41 & 204.51 & 68.71 \\
\hline Isoleucine $(\mu g)$ & $3420.25^{*}$ & 542.13 & 4428.68 & 811.33 \\
\hline Leucin $(\mu g)$ & $5396.44^{*}$ & 722.69 & 6936.07 & 1085.79 \\
\hline Lysine $(\mu g)$ & $5166.29^{*}$ & 743.07 & 6373.49 & 1153.43 \\
\hline Methionine $(\mu g)$ & 1722.42 & 306.55 & 2083.06 & 408.20 \\
\hline Cystine $(\mu g)$ & $791.56^{\star}$ & 174.99 & 1298.58 & 252.85 \\
\hline Phenylalanine $(\mu g)$ & $2940.61^{*}$ & 387.50 & 3934.61 & 564.00 \\
\hline Tyrosine $(\mu \mathrm{g})$ & $2667.02^{*}$ & 415.99 & 3211.78 & 617.02 \\
\hline Threonine $(\mu g)$ & $2939.37^{*}$ & 438.24 & 3758.54 & 651.20 \\
\hline Tryptophan ( $\mu g)$ & $899.94^{*}$ & 174.04 & 1159.94 & 256.24 \\
\hline Valine $(\mu g)$ & $4110.42^{*}$ & 645.71 & 5317.93 & 970.71 \\
\hline Arginine $(\mu g)$ & $3228.82^{*}$ & 530.89 & 4854.34 & 1189.50 \\
\hline Histidine $(\mu g)$ & 2220.55 & 798.52 & 2510.24 & 631.34 \\
\hline Alanine $(\mu g)$ & $3374.50^{*}$ & 615.96 & 4479.03 & 893.42 \\
\hline Aspartic acid $(\mu g)$ & $5969.93^{*}$ & 891.49 & 8438.15 & 1656.24 \\
\hline Glutamic acid $(\mu g)$ & $12861.99^{*}$ & 1731.61 & 17749.71 & 2736.48 \\
\hline Glycine $(\mu g)$ & $2783.42^{*}$ & 554.83 & 3868.23 & 643.66 \\
\hline Proline $(\mu g)$ & $4852.76^{*}$ & 685.74 & 6104.62 & 1079.38 \\
\hline Serine $(\mu g)$ & $3443.21^{*}$ & 559.67 & 4431.37 & 678.53 \\
\hline Saccharide (g) & $14.45^{*}$ & 8.19 & 20.73 & 6.29 \\
\hline Lactose (g) & $12.25^{\star}$ & 5.10 & 18.31 & 8.76 \\
\hline Starch (g) & $52.14^{*}$ & 18.18 & 128.96 & 35.95 \\
\hline Dietary fibre (g) & $14.78^{*}$ & 1.94 & 37.68 & 4.88 \\
\hline Alcohol (g) & 0.00 & 0.00 & 0.00 & 0.00 \\
\hline Folacin - diet eq. $(\mu g)$ & $217.90^{*}$ & 69.81 & 593.52 & 117.26 \\
\hline Vitamin B12 ( $\mu \mathrm{g})$ & 4.32 & 2.41 & 4.07 & 1.46 \\
\hline Vitamin D ( $\mu g)$ & 3.71 & 3.78 & 3.52 & 3.76 \\
\hline Iodine $(\mu g)$ & 49.19 & 34.66 & 59.17 & 11.91 \\
\hline $\begin{array}{l}\text { Long-chain polyunsa- } \\
\text { turated fatty acids (g) }\end{array}$ & 0.74 & 0.98 & 0.70 & 0.92 \\
\hline $\begin{array}{l}\text { Absorbable } \\
\text { carbohydrates (g) }\end{array}$ & $98.33^{*}$ & 15.62 & 233.70 & 20.62 \\
\hline \% energy from protein & $26.91^{*}$ & 3.04 & 20.46 & 2.79 \\
\hline$\%$ energy from fat & $34.65^{*}$ & 3.35 & 27.35 & 3.19 \\
\hline $\begin{array}{l}\text { \% energy from } \\
\text { carbohydrates }\end{array}$ & $38.44^{*}$ & 4.38 & 52.19 & 4.38 \\
\hline
\end{tabular}

* statistically significant differences $p \leq 0.05$ 
protein, below $30 \%$ energy from fat and $52 \%$ of energy from carbohydrates. The contents of nutrients and energy in the diet are presented in Table 3. The average content of nutrients in a 7-day diet covered the demand of an organism for analysed components. Each menu was composed of 5 meals including wholemeal grain products, 5 portions of vegetables, 3 portions of dairy and fish and 2 portions of meat and its high-quality products. Calorie load, dietary fibre and minerals were supplied by 2 portions of fruits with low glycemic index and by seeds and grains. Such objectives should lead to weight loss from $0.5 \mathrm{~kg}$ to $1 \mathrm{~kg}$ a week, depending on individual characteristics of a patient and physical activity [14].

\section{Dietary recommendations for patients subjected to bariatric surgery}

The patients subjected to bariatric surgery (RYGB or SG) used a diet prepared according to Dietary recommendations after bariatric procedures [15]. The diet was low in energy (significantly below BMR), containing, on average, $69 \mathrm{~g}$ of protein (26.9\%), $40 \mathrm{~g}$ of fat $(34.6 \%)$ and $113 \mathrm{~g}$ of carbohydrates $(38.4 \%)$. The diet for patients after the bariatric procedure was deficient in the supply of vitamins, nutrients and dietary fibre, which was a necessary limitation after the surgery. Nutrients' contents in first months of the diet are presented in Table 3.

\section{Results and statistical analyses}

Energy and nutrient contents were analysed using Dieta 5D software recommended by the National Food and Nutrition Institute (Warsaw, Poland). The reduction of body weight in women after bariatric surgery was compared to estimated body mass reduction based on reduced caloric intake. Statistical calculations were performed using Statistica 12 (Statsoft, Tulsa, Oklahoma, USA). Arithmetical mean, standard deviation and statistically significant differences were calculated using ANOVA. The test for dependant samples was performed using $\mathrm{p} \leq 0.05$ level of significance.

\section{RESULTS}

The average body weight of female patients before the bariatric surgery was $131.56 \mathrm{~kg}$ (SD 14.8); average height was 168.37 cm (SD 8.69); average age was 42.96 (SD 10.45). The average reduction in daily caloric intake was $1930 \mathrm{kcal}$, whereas the caloric intake after bariatric surgery was only $1036 \mathrm{kcal}$. The diet after bariatric surgery contained $69 \mathrm{~g}$ of protein $(26.9 \%)$, $40 \mathrm{~g}$ of fat (34.6\%) and $113 \mathrm{~g}$ of carbohydrates (38.4\%). The diet for patients after the surgery provided insufficient intake of potassium (2056 mg), calcium (525 mg), magnesium (234 mg), iron (7 mg), zinc (7.4 mg), vitamins: E (7.4 mg), B1 (0.8 mg), $\mathrm{D}(3.7 \mu \mathrm{g})$, folic acid $(217 \mu \mathrm{g})$, iodine $(49 \mu \mathrm{g})$ and dietary fibre (14.7 g). In the properly composed reduction diet the deficiency in nutrients was not observed. The contents of nutrients in both diets is presented in Table 3 .

Body mass reduction in reduction diet after 13 months should reach from $26-41.6 \mathrm{~kg}$ (on average $33.8 \mathrm{~kg}$ ). After 13 months

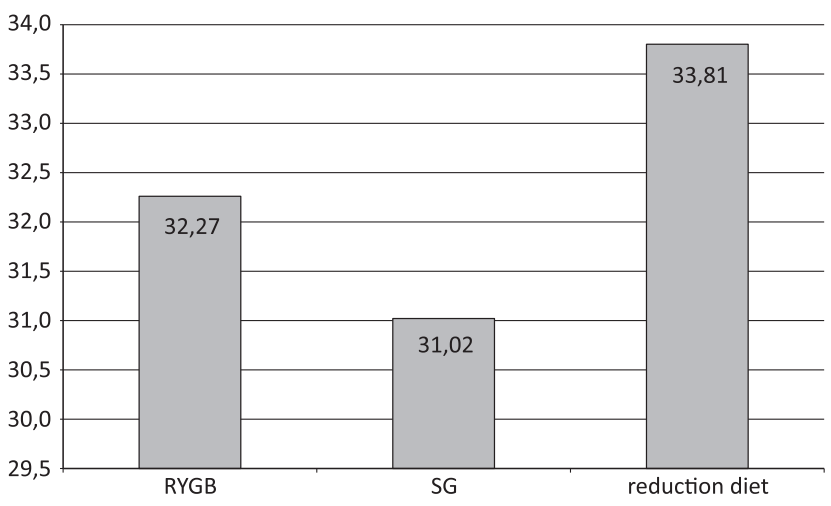

RYGB - Roux-en-Y bypass; SG - sleeve gastrectomy

FIGURE 1. Average body weight reduction (kg) after 13 months

from bariatric surgery the reduction of body weight in case of RYGB amounted to $32.27 \mathrm{~kg}$ (SD 13.9) and in case of SG - $31.02 \mathrm{~kg}$ (SD 12.3), which was presented in Figure 1.

\section{DISCUSSION}

The brain is the organ responsible for the reception and processing of signals related to the beginning or ending of meal consumption. The appestat regulated by the systems located in hypothalamus is influenced by the concentration of glucose and free fatty acids in the blood, genetic, psychical, nervous and hormonal factors, and by the changes in thermal regulation caused by the specific dynamic action of food. Additionally, the regulation of appetite and satiety is affected by the signals, which reach the hypothalamus from the digestive system and adipose tissue $[16,17]$. Lateral hypothalamus is responsible for the sensation of hunger through the neurons related to neuropeptide $\mathrm{Y}$, whereas medial hypothalamic nucleus is associated with satiety through the neurons related to proopiomelanocortin. Leptin - a protein made mainly by adipose cells, has the ability to pass through the blood-brain barrier and inhibit the activity of neurons related to agouti-related peptide (decreases energy expenditure) and neuropeptide $Y$ (appetite stimulator). Leptin also stimulates the expression and release of $\alpha$-melanocyte-stimulating hormone in arcuate nucleus leading to the feeling of satiety.

Among the many homeostatic mechanisms in the organism the concentration of glucose is the most precisely regulated. Glucose in the blood can come from food or, when the intake of carbohydrates is insufficient, the organism produces glucose from non-carbohydrate compounds (glycogenic amino acids, lactate, glycerol) via gluconeogenesis [18]. The hormones acting in an opposite way to insulin, i.e. aiming at increasing the level of glucose in blood in response to hypoglycaemia, are: glucagon, hormones of anterior pituitary lobe - growth hormone and adrenocorticotropic hormone, glucocorticosteroids and adrenaline, which is secreted by adrenal medulla also under stress.

Improperly balanced diet, too long breaks between meals and used culinary techniques have enormous effect on our nutritional status. Surgical obesity treatment requires careful consideration of all advantages and disadvantages between 
progressing and untreatable chronic diseases related to obesity and potential complications and side effects of surgical interventions leading to chronic malnutrition [19, 20].

Bariatric surgery not only results in physical reduction of the amount of consumed food but it also disrupts some of the hormonal pathways [21]. Bypassing the stomach excludes the fundus of the stomach and duodenum, where ghrelin - an orexigenic hormone - is synthesised. In patients after RYGB procedure the reduction of the concentration of insulin and leptin was observed, the hormones responsible for the intake of reduced amount of food [20]. Bariatric surgeries also affect the secretion of incretins (GLP-1, GIP, YY peptide and ghrelin), the hormones of digestive system, which induce the release of insulin from pancreatic beta cells under food consumption.

Unfortunately, the effects of body mass reduction via bariatric procedures are diminished by possible occurrence of many complications [22]. Roux-en-Y bypass procedure is related to almost $40 \%$ risk of development of cholelithiasis 6 months after the surgery. Drastic body weight loss, nutritional deficiencies and increased concentration of parathormone in blood lead to reconstruction and decreased bones density [23].

Roux-en-Y bypass can also be related to the risk of the development of dumping syndrome even in $40 \%$ of patients. The symptoms of this syndrome relate to rapid emptying of the stomach or abrupt exposition of small intestine to nutrients. Clinical symptoms are divided into early (stomach ache, diarrhoea, also hypertension, palpitation and hot flushes) and late (symptoms of hypoglycaemia: hunger, sweating, weakness, disorientation, fainting). Roux-en-Y bypass method should not be used in people suffering from inflammatory bowel disease and Lesniowski-Crohn's disease, because these diseases unable to form the bypass. However, recent studies have shown that such patients are also subjected to bariatric surgeries [24, 25].

If we consider psychic condition of bariatric patient it turns out that ca. $40 \%$ of patients had at least one psychiatric diagnosis and the most common disorders were depression, anxiety or eating disorders. Even though the quality of life significantly improves for the patients immediately after bariatric surgery, the initial postoperative improvement in psychic functionality diminishes over 2-3 years after the procedure. In patients subjected to bariatric surgeries a higher suicide ratio was observed (in patients 2-8 years after the procedure), as compared to the general population [9]. Deteriorated psychical health in patients after bariatric surgery could result from their little adjustment to experience social acceptance due to undeveloped social functioning. It could also be caused by the fact that longstanding personality disorders had been masked by the patient by excessive food consumption and were revealed once body weight was reduced. The diet after bariatric surgery is non-physiological, deficient and lacks in energy (often below BMR) which can facilitate the development of such diseases as: osteoporosis, anaemia due to iron and folacin deficits, hypothyroidism, disrupted peristalsis and depression. Thus, it seems that in bariatric patients we should introduce supplementation or even feeding with special dietary foods with higher density of nutrients, vitamins and minerals. However, an additional issue appears, as we do not know whether the nutrients would be absorbed well and, moreover, we do not know the composition of such supplement. Reduction diet based on rational diet allows to adapt to changes, does not lead to hepatic steatosis, results in less intensive lipolysis than in case of bariatric surgery [25], supplies appropriate amounts of vitamins and minerals and, more importantly, develops rational and appropriate dietary habits, which can be maintained for the rest of life.

Taking all the above observations into consideration and the effect of body mass reduction obtained by restrictive bariatric procedures and this obtained by using rational restrictive diet, which is comparable, it could be assumed that the most rational method of fighting with obesity is to provide long-term dietary and psychological care to the patient and treat obesity with non-invasive methods. At the same time it should be stressed that there are patients for whom bariatric surgeries will be the best obesity treatment alternative but such patients should be cared for by a multidisciplinary group of medical specialists [26].

\section{CONCLUSIONS}

Body mass reduction by diet with lowered caloric load and through the introduction of increased physical activity can be at least as effective way to treat obesity as bariatric surgery. Due to numerous complications occurring after bariatric surgeries, long-term deficiencies of nutrients in a diet and improper dietary habits, bariatric surgery should be treated as a last resort in obesity treatment. In both cases the long-term care of a dietician and a psychologist seems to be necessary.

\section{REFERENCES}

1. Huypens P, Sass S, Wu M, Dyckhoff D, Tschöp M, Theis F, et al. Epigenetic germline inheritance of diet-induced obesity and insulin resistance. Nat Genet 2016;48(5):497-9. doi: 10.1038/ng.3527.

2. Cena H, De Giuseppe R, Biino G, Persico F, Ciliberto A, Giovanelli A, et al. Evaluation of eating habits and lifestyle in patients with obesity before and after bariatric surgery: a single Italian center experience. Springerplus 2016;5(1):1467. doi: 10.1186/s40064-016-3133-1.

3. Fichna P, Skowrońska B. Obesity and metabolic syndrome childrens and young people. Otyłość oraz zespół metaboliczny u dzieci i młodzieży. Family Med Primary Care Rev 2008;10(2):269-78.

4. Schauer PR, Ikramuddin S, Gourash W, Ramanathan R, Luketich J. Outcomes after laparoscopic Roux-en-Y gastric bypass for morbid obesity. Ann Surg 2000;232(4):515-29.

5. Barja-Fernández S, Folgueira C, Seoane LM, Casanueva FF, Dieguez C, Castelao $\mathrm{C}$, et al. Circulating betatrophin levels are increased in anorexia and decreased in morbidly obese women. J Clin Endocrinol Metab 2015;100(9):E1188-96. doi: 10.1210/JC.2015-1595.

6. Herpertz-Dahlmann B. Adolescent eating disorders: update on definitions, symptomatology, epidemiology, and comorbidity. Child Adolesc Psychiatr Clin N Am 2015;24(1):177-96. doi: 10.1016/j.chc. 2014.08.003.

7. Fica S, Sirbu A. Metabolic surgery for diabetes mellitus between benefits and risks. Acta Endo (Buc) 2015;11(2):212-19. doi: 10.4183/aeb.2015.212.

8. Leahy CR, Luning A. Review of nutritional guidelines for patients undergoing bariatric surgery. AORN J 2015;102(2):153-60. doi: 10.1016/j. aorn.2015. 05.017. 
9. Canetti L, Bachar E, Bonne 0. Deterioration of mental health in bariatric surgery after 10 years despite succesful weight loss. Eur J Clin Nutr 2016;70:17-22.

10. Szczuko M, Komorniak N, Hoffmann M, Walczak J, Jaroszek A Kowalewski B, et al. Body weight reduction and biochemical parameters of the patients after RYGB and SG bariatric procedures in 12-month observation. Obes Surg 2017;27(4):940-7. doi:10.1007/s11695-016-2400-0.

11. Lubrano C, Mariani S, Badiali M, Cuzzolaro M, Barbaro G, Migliaccio S, et al. Adipokine profile and insulin sensitivity in formerly obese women subjected to bariatric surgery or diet-induced long-term caloric restriction. J Gerontol A Biol Sci Med Sci 2010;65A(9):915-23.

12. Benaiges D, Más-Lorenzo A, Goday A, Ramon JM, Chillarón JJ, Pedro-Botet J, et al. Laparoscopic sleeve gastrectomy: More than a restrictive bariatric surgery procedure? World J Gastroenterol 2015;21(41):11804-14. doi: 10.3748/wjg.v21.i41.11804.

13. Kawasaki T, Ohta M, Kawano Y, Masuda T, Gotoh K, Inomata M, et al. Effects of sleeve gastrectomy and gastric banding on the hypothalamic feeding center in an obese rat model. Surg Today 2015;45(12):1560-6. doi: 10.1007/s00595-015-1135-1.

14. Ciborowska H, Rudnicka A. Dietetyka. Żywienie zdrowego i chorego człowieka. 3nd ed. Warszawa: Wyd. Lekarskie PZWL; 2007.

15. Jastrzębska M, Ostrowska L. Zalecenia dietetyczne po zabiegach bariatrycznych. Forum Zaburzeń Metabolicznych 2010;1(4):201-9.

16. Rui L. Brain regulation of energy balance and body weight. Rev Endocr Metab Disord 2013;14(4):387-407. doi: 10.1007/s11154-013-9261-9.
17. Jebst EE, Enriori PJ, Sinnayah P, Cowley MA. Hypothalamic regulatory pathways and potential obesity treatment targets. Endocrine 2006;29(1):33-48.

18. Murray RK, Granner DK, Rodwell VW. Biochemia Harpera. 4rd ed. Warszawa: Wyd. Lekarskie PZWL; 2012.

19. Sattar N, Lean M, Pupek-Musialik D, editors. Abc otyłości. Warszawa: Wyd. Lekarskie PZWL; 2009.

20. Fischer L, Hildebrandt C, Bruckner T, Kenngott H, Linke GR, Gehrig T, et al. Excessive weight loss after sleeve gastrectomy: a systematic review. Obes Surg 2012;22(5):721-31. doi: 10.1007/s11695-012-0616-1.

21. Jammah AA.. Endocrine and metabolic complications after bariatric surgery. Saudi J Gastroenterol 2015;21(5):269-77. doi: 10.4103/13193767.164183.

22. Tatoń J, Czech A, Bernas M. Otyłość. Zespół metaboliczny. Warszawa: Wyd. Lekarskie PZWL; 2007.

23. Pizzorno L. Bariatric surgery: bad to the bone, part 2. Integr Med (Encinitas) 2016;15(2):35-46.

24. Aminian A, Andalib A, Ver MR, Corcelles R, Schauer PR, Brethauer SA. Outcomes of bariatric surgery in patients with inflammatory bowel disease. Obes Surg 2016;26(6):1186-90. doi: 10.1007/s11695-015-1909-y.

25. Keidar A, Hazan D, Sadot E, Kashtan H, Wasserberg N. The role of bariatric surgery in morbidly obese patients with inflammatory bowel disease. Surg Obes Relat Dis 2015;11(1):132-6. doi: 10.1016/j.soard.2014.06.022.

26. Lanzi $P$, Noè D, Ventura $P$, Vitali T, Giuffrè $M$, Spiti R, et al. Outcomes of bariatric surgery: clinical benefits versus short-term and long-term complications. Nutritional Therapy Metabol 2011;29(3):124-33. 